\title{
Royal Jelly and Its Dual Role in TNBS Colitis in Mice
}

\author{
Luis Paulo Manzo, ${ }^{1,2}$ Felipe Meira de-Faria, ${ }^{1,2}$ Ricardo José Dunder, ${ }^{1}$ \\ Eduardo Augusto Rabelo-Socca, ${ }^{1}$ Silvio Roberto Consonni, ${ }^{3}$ Ana Cristina Alves de Almeida, ${ }^{2}$ \\ Alba Regina Monteiro Souza-Brito, ${ }^{1,2}$ and Anderson Luiz-Ferreira ${ }^{4}$ \\ ${ }^{1}$ Department of Pharmacology, Faculty of Medical Sciences, University of Campinas (UNICAMP), 13083-970 Campinas, SP, Brazil \\ ${ }^{2}$ Department of Structural and Functional Biology, Institute of Biology, University of Campinas (UNICAMP), \\ 13083-970 Campinas, SP, Brazil \\ ${ }^{3}$ Department of Biochemistry and Tissue Biology, Institute of Biology, University of Campinas (UNICAMP), \\ 13083-970 Campinas, SP, Brazil \\ ${ }^{4}$ Department of Biological Sciences, Federal University of Goiás (UFG), Regional Catalão, 75704-020 Catalão, GO, Brazil
}

Correspondence should be addressed to Anderson Luiz-Ferreira; luiz_ferreira@ufg.br

Received 28 July 2014; Revised 15 October 2014; Accepted 22 October 2014

Academic Editor: Inaya Hajj Hussein

Copyright (C) 2015 Luis Paulo Manzo et al. This is an open access article distributed under the Creative Commons Attribution License, which permits unrestricted use, distribution, and reproduction in any medium, provided the original work is properly cited.

\begin{abstract}
Royal Jelly (RJ) is widely consumed in diets throughout the world due to its beneficial effects: antioxidant, antitumor and antiinflammatory. We have investigated the role of RJ in the development of TNBS colitis in mice. Colitis was induced by a rectal instillation of TNBS at $0.1 \mathrm{~mL}$ per mouse. Intestine samples of the animals orally treated with RJ (100, 150, and $200 \mathrm{mg} / \mathrm{kg})$ were collected for antioxidant assays (GSH and GSH-Px), proinflammatory protein quantification (COX-2 and NF- $\kappa \mathrm{B}$ ), and histological analyses. RJ $100 \mathrm{mg} / \mathrm{kg}$ maintained GSH levels and increased the activity of GSH-Px, downregulated key inflammatory mediators (COX-2 and NF- $\kappa \mathrm{B})$, and decreased the lesions caused by TNBS as shown by the histological analyses. In conclusion, RJ showed anti-inflammatory and antioxidant properties in experimental colitis, resulting in the amelioration of the macroscopic and histological analyses. These results corroborate with the RJ supplementation in diets.
\end{abstract}

\section{Introduction}

Royal jelly (RJ) is an important functional food item that possesses several health-promoting properties and has been widely used in commercial medical products, healthy foods, and cosmetics in many countries [1]. The myriad effects accredited to RJ are comprehensible due to its richness in vitamins, minerals, proteins, amino acids, and carbohydrates [2]. Some of its accredited properties are immunomodulation [3] anti-inflammatory [4], healing [5], and antiaging [6]. It is a nourishing substance secreted by the mandibular and hypopharyngeal glands of worker honey bees Apis mellifera [7]. On one hand, royal jelly is accredited to exert many beneficial effects to the body; on the other, there are some reports of anaphylactic shock, allergy, and acute colitis due to its intake [8-10]. Recently, due to the biological effects accredited to $\mathrm{RJ}$, its use has been increasing throughout the world, which, in turn, has been attracting enormous attention from the scientific community. It is already known that highly reactive free radicals are formed by either exogenous chemicals or endogenous metabolic processes of the body. These free radicals are capable of oxidizing biomolecules, resulting in tissue damage and consequent cell death [11] in various pathological processes including inflammatory bowel disease $[12,13]$.

Ulcerative colitis (UC) and Crohn's disease (CD) are the two major forms of inflammatory bowel diseases (IBD). Both $\mathrm{UC}$ and $\mathrm{CD}$ are of complex etiology and are believed to arise from the interaction of genetic, environmental, and microbial factors [14]. These two forms of IBD occur in the large intestine, although $\mathrm{CD}$ may affect the whole digestive tract while UC tends to be restricted to the distal portion of the tube (rectum) [15]. Either CD or UC presents ulcerated areas; the first shows a transmural lesion, affecting the entire wall thickness (from the mucosa to the serosa). The second is shallower, affecting the mucosal lining only. Many authors have proposed that these intestinal conditions are mediated 
by the activation of both lymphocytes and nonlymphoid cells such as macrophages and neutrophils. Once a vast number of these cells are activated, they migrate to the harmed mucosa site, leading to an overproduction of oxygen free radicals that may damage or even kill the cells in the inflamed area [16].

The antioxidant and anti-inflammatory mechanisms are of crucial importance to the homeostasis and integrity of the bowel. Since scientists have not developed an effective drug for the IBD treatment yet [9], new and alternative therapies arise not only as a promise but, rather, as a necessity for the patients undergoing such conditions. Due to the antiinflammatory [4] and antioxidant properties of RJ [1], the oxidative stress taking place in the intestine of UC and $\mathrm{CD}$ patients, and a study reporting that RJ was effective at attenuating acetic acid-induced colitis in rats [17], our group decided to investigate whether an oral pretreatment with RJ would have any effect on mice submitted to TNBS-induced colitis.

\section{Materials and Methods}

2.1. Animals. Unib-SW 6-8-week-old female mice were purchased from CEMIB-UNICAMP. All the protocols used in this study were in accordance with the Ethics Committee on the Use of Experimental Animal (CEUA) from UNICAMP (2398-1). All animals had free access to tap filtered water and certified rodent chow (Nuvilab) during the whole experiment. Room temperature was kept constant with 12/12 light dark cycles $60 \pm 1 \%$ humidity and a temperature of $21 \pm 2^{\circ} \mathrm{C}$.

2.2. Drugs, Reagents, and Royal Jelly. All drugs and reagents were prepared right before use and were of chemical grade. 2,4,6-Trinitrobenzene sulfonic acid (TNBS) and $\mathrm{NaCl}$ were bought from Sigma (MO, USA). Royal Jelly was obtained from Baldoni apiary (São Paulo, Brazil) and solubilized in saline $0,9 \%$ with 5 minute-sonication and heavy agitation in vortex. Following agitation, the solution was collected and diluted at test doses $(100,150$, and $200 \mathrm{mg} / \mathrm{kg}$ of animal).

2.3. Experimental Protocols. Mice were randomly assigned into five groups $(n=10)$ : noncolitic saline, negative control group TNBS, in which none received royal jelly and the other 3 groups received, orally, daily for 19 days, 100, 150, and $200 \mathrm{mg} / \mathrm{kg}$ of royal jelly (suspended in saline $10 \mathrm{~mL} / \mathrm{kg}$ ). Both saline and TNBS groups were given $10 \mathrm{~mL} / \mathrm{kg}$ of saline daily. Two weeks after pretreatment started, mice from the TNBS and RJ pretreated groups (100,150, and $200 \mathrm{mg} / \mathrm{kg}$ ) (Figure 5) were rendered colitis by the method originally described by Morris et al. [18]. Briefly, they were anaesthetized with halothane and given $10 \mathrm{mg}$ of 2,4,6-trinitrobenzenesulfonic acid (TNBS) dissolved in $0.1 \mathrm{~mL}$ of $50 \%$ ethanol (v/v) through a Teflon cannula inserted $4 \mathrm{~cm}$ through the anus. Mice from the noncolitic group were administered intracolonically $0.25 \mathrm{~mL}$ of phosphate-buffered saline instead of TNBS. Behavior, body weight, and stool consistency were recorded daily throughout the experiment. All mice were killed by cervical dislocation 4 days after induction of colitis and the colon was removed and placed on cold plate and longitudinally cut into two slices.
2.4. Macroscopic Features of Colitis. The severity of colon damage was macroscopically assessed using the criteria previously established for TNBS-induced colitis [19]. A score ranging from 0 to 10 was employed, as follows: 0 , no damage; 1 , hyperaemia without ulcers; 2, hyperaemia and wall thickening without ulcers; 3 , one ulceration site without wall thickening; 4 , two or more ulceration sites; $5,0.5 \mathrm{~cm}$ extension of inflammation or major damage; and $6-10,1 \mathrm{~cm}$ extension of inflammation or severe damage. The score was increased by 1 for every $0.5 \mathrm{~cm}$ of damage up to a maximal score of 10 ; by 0 or 1 for absence or presence of diarrhea and 0,1 , or 2 for absence, presence of mild or severe adhesion, respectively.

2.5. Histological Features of Colitis. The colon was dissected and fixed with $4 \%$ paraformaldehyde (Merck, Darmstadt, Germany) in $0.1 \mathrm{M}$ phosphate-buffered saline (PBS; $\mathrm{pH} 7.4$ ) for $24 \mathrm{~h}$ at $4^{\circ} \mathrm{C}$. The tissues of three animals per experimental group were dehydrated in graded concentrations of alcohol, embedded in historesin (Leica Microsystems, Heidelberg, Germany) and sectioned transversely at a width of $2 \mu \mathrm{m}$. The resulting serial sections were mounted on slides, stained with hematoxylin and Floxin and imaged using a Nikon Eclipse E800 light microscope. The images were then qualitatively examined by histopathologists in double-blind experiment. The qualitative histopathological analysis focused on changes of the epithelium integrity, oedema, lymphocytic infiltration, cytoplasmic vacuolization, and necrosis.

2.6. Glutathione Level Determination (GSH). GSH levels of colonic tissue of animals were determined by Ellman's reaction using $5^{\prime} 5^{\prime}$-dithiobis-2-nitrobenzoic acid (DTNB) as described by Anderson [20]. The intensity of the yellow colour was read at $412 \mathrm{~nm}$.

2.7. Glutathione Peroxidase Activity (GSH-Px). GSH-Px activity was quantified by following the decrease in absorbance at $365 \mathrm{~nm}$ induced by $0.25 \mathrm{mM} \mathrm{H}_{2} \mathrm{O}_{2}$ in the presence of reduced glutathione $(10 \mathrm{mM}), \mathrm{NADPH},(4 \mathrm{mM})$, and $1 \mathrm{U}$ enzymatic activity of GSH-Px [21].

2.8. Western Blotting Analyses. Frozen colon samples were homogenized in $1 \mathrm{~mL}$ of cold buffer containing phosphate buffer (PB) $0.1 \mathrm{M}, \mathrm{pH} 7.4$, and protease inhibitor cocktail 1\% (Sigma-Aldrich P-8340). Homogenates were centrifuged $\left(12,000 \times \mathrm{g}, 45 \mathrm{~min}, 4^{\circ} \mathrm{C}\right)$ and the supernatants were collected and stored at $-80^{\circ} \mathrm{C}$. Different centrifugation times and buffers were used for the cytosolic $\left(14,000 \times \mathrm{g}, 45 \mathrm{~min}, 4^{\circ} \mathrm{C}\right)$, membrane $\left(14,000 \times \mathrm{g}, 45 \mathrm{~min}, 4^{\circ} \mathrm{C}\right)$, and nuclear extracts $\left(15,000 \times \mathrm{g}, 60 \mathrm{~min}, 4^{\circ} \mathrm{C}\right)$ respectively, according to Helenius et al. (1996) with modifications [22]. Protein concentration of the homogenate was determined following Bradford's colorimetric method Bradford [23]. Then, samples were treated with Laemmli buffer (PB 0.5 M, pH 6.8; glycerol, sodium dodecyl sulfate (SDS) $10 \%$, bromophenol $0.1 \%$, and $\beta$-mercaptoethanol) [24] in a 1:1 proportion. Equal amounts of protein from samples $(70 \mu \mathrm{g})$ were separated on $8 \%$ acrylamide gel by sodium dodecyl sulfate polyacrylamide gel electrophoresis. In the next step, proteins were electrophoretically transferred onto a nitrocellulose membrane and incubated 
TABLE 1: Effect of royal jelly on the disease activity index of mice undergoing TNBS-induced colitis.

\begin{tabular}{lccc}
\hline Group & $\begin{array}{c}\text { Macroscopic } \\
\text { assessment }\end{array}$ & Adhesion & Diarrhea \\
\hline Noncolitic (saline) & $0 \pm 0^{\mathrm{b}}$ & $0 \pm 0^{\mathrm{b}}$ & $0 \pm 0^{\mathrm{b}}$ \\
Colitic (TNBS) & $4.5 \pm 0.42$ & $1.5 \pm 0.54$ & $0.71 \pm 0.48$ \\
RJ $100 \mathrm{mg} / \mathrm{kg}$ & $2.56 \pm 0.29^{\mathrm{a}}$ & $0.44 \pm 0.72^{\mathrm{a}}$ & $0.67 \pm 0.5$ \\
RJ $150 \mathrm{mg} / \mathrm{kg}$ & $2.67 \pm 0.236^{\mathrm{a}}$ & $0.625 \pm 0.91$ & $0.62 \pm 0.51$ \\
RJ $200 \mathrm{mg} / \mathrm{kg}$ & $3.88 \pm 0.515$ & $1.38 \pm 0.91$ & $0.750 \pm 0.46$ \\
\hline
\end{tabular}

Results are presented as mean \pm SEM. ANOVA followed by Dunnett's $t$-test. ${ }^{\mathrm{a}} P<0.05$ and ${ }^{\mathrm{b}} P<0.001$ are significantly different from colitic nontreated group.

with specific primary antibodies: COX-2 (160126) (Cayman Chemical, USA) at 1:500 dilution and NF- $\kappa$ B (MAB 2697) (R\&D Systems, USA) at 1:2000. Each membrane was washed three times for $10 \mathrm{~min}$ and incubated with HRP-Goat AntiRabbit (Invitrogen 656120) (COX-2, diluted at 1:5000). To prove equal loading, the blots were analyzed with standard protein Ponceau dye [24]. Immunodetection was performed using enhanced chemiluminescence light-detecting kit (SuperSignal West Femto Chemiluminescent Substrate, Pierce, IL, USA). Densitometric data were performed with G-BOX, Syngene, following normalization to the control (Ponceau) by GeneSys software.

2.9. Statistical Analysis. Results were expressed as mean \pm standard error of means (SEM). The statistical significance of each test group in relation to the control was calculated using ANOVA followed by Dunnett's $t$-test.

\section{Results}

3.1. Macroscopic Evaluation of Colitis. Mice subjected to royal jelly pretreatment showed an overall lower impact of TNBSinduced colonic damage compared with the TNBS control group. Macroscopic inspection showed evidence of severe colonic mucosal damage, with oedema, deep ulcerations, and hemorrhage in TNBS group. The doses of 100 and $150 \mathrm{mg} / \mathrm{kg}$ significantly diminished the damage provoked by the hapten $(P<0.05)$ (Table 1$)$. When evaluating the adhesion parameter only, the dose of $100 \mathrm{mg} / \mathrm{kg}$ was capable of preventing its aggravation. The treated mice with RJ (100 and $150 \mathrm{mg} / \mathrm{kg}$ ) showed a faster weight recovery than those of the TNBS group (Figure 1). However, mice from the TNBS control group showed a lower weight recovery throughout the experiment in comparison with the mice from the noncolitic group $(P<0.05)$. All the other experiments were performed using only the lowest effective dose.

3.2. Histological Evaluation of Colitis. The effective induction of TNBS-induced inflammation was corroborated by the loss of epithelium integrity, oedema, and inflammatory infiltrate as shown in Figures 2(a)-2(e). Figure 2 summarizes the tissue damage from all groups, colitic and noncolitic (Saline, TNBS, RJ 100, 150, and $200 \mathrm{mg} / \mathrm{kg}$ ). Qualitatively, the noncolitic group saline showed a normal mucosa of the colon with an

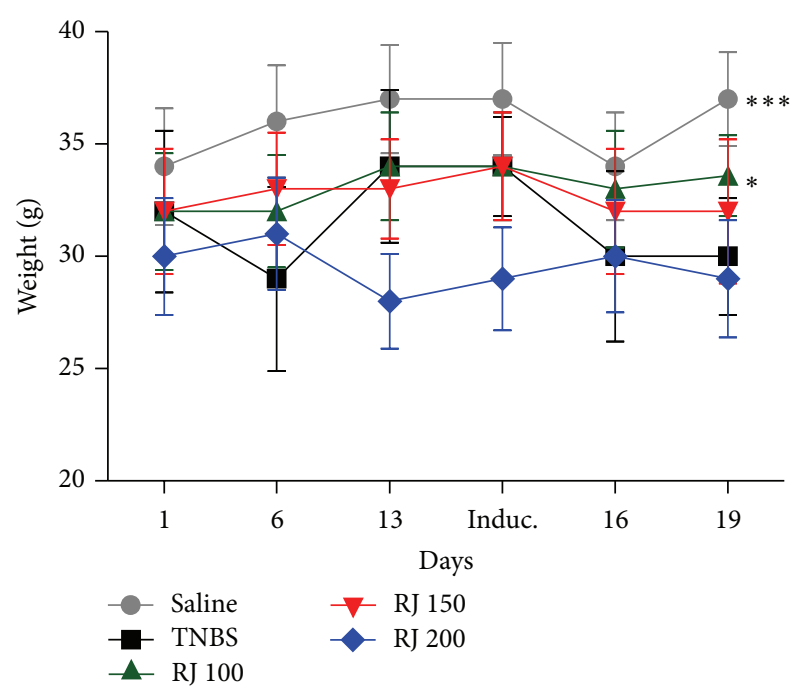

FIGURE 1: Weight means of the 5 different groups on days 1, 6, and 13 (before induction) and 16 and 19 (after induction). Data is presented as mean \pm SEM. Two-way ANOVA followed by Bonferroni's $t$-test. ${ }^{*} P<0.05,{ }^{* * *} P<0.001$ are significantly different from TNBS group.

intact simple columnar epithelium and numerous goblet cells. The crypts of Lieberkühn are straight and unbranched and lined largely with goblet cells. The appearance of the lamina propria is consisted by soft connective tissue, leukocytes, and the muscularis mucosae. Next, the submucosa of this group is made of irregular connective and adipose tissue, numerous blood vessels, and several ganglion cells and nerves of the submucosal plexus.

However, the TNBS-colitic control group showed an extensively loss of epithelium integrity (ulceration) and crypts, loss of goblet cells, and no definite mucosal lining as well as a great number of inflammatory cells that might indicate necrosis. The RJ $100 \mathrm{mg} / \mathrm{kg}$ group showed a decreased number of goblet cells, moderate cell infiltrate, mainly neutrophils, and a low intensity oedema when compared with TNBS colitic group. The RJ $150 \mathrm{mg} / \mathrm{kg}$ group showed as many goblet cells as noncolitic group saline and an apparently better epithelium integrity; on the other hand, the number of inflammatory cells is qualitatively higher when compared to RJ 100 group. The RJ $200 \mathrm{mg} / \mathrm{kg}$ group showed a massive infiltrate and no delimitations of either the mucosal lining or epithelium, similarly to the TNBS control group.

3.3. Glutathione Level Determination (GSH). The GSH levels in the noncolitic group were high and after TNBS colitis induction the GSH levels drastically reduced; on the other hand, RJ $100 \mathrm{mg} / \mathrm{kg}$ was capable of preventing the decrease in the levels of GSH after colitis induction. Interestingly, the protection of GSH levels exerted by RJ $100 \mathrm{mg} / \mathrm{kg}$ was similar to those of the noncolitic group (Table 2).

3.4. Glutathione Peroxidase Activity (GSH-Px). The noncolitic (saline) and colitic (TNBS) groups were the same regarding GSH-Px activity. RJ at the doses of $100 \mathrm{mg} / \mathrm{kg}$ was able to increase the activity of GSH-Px (Table 2). 

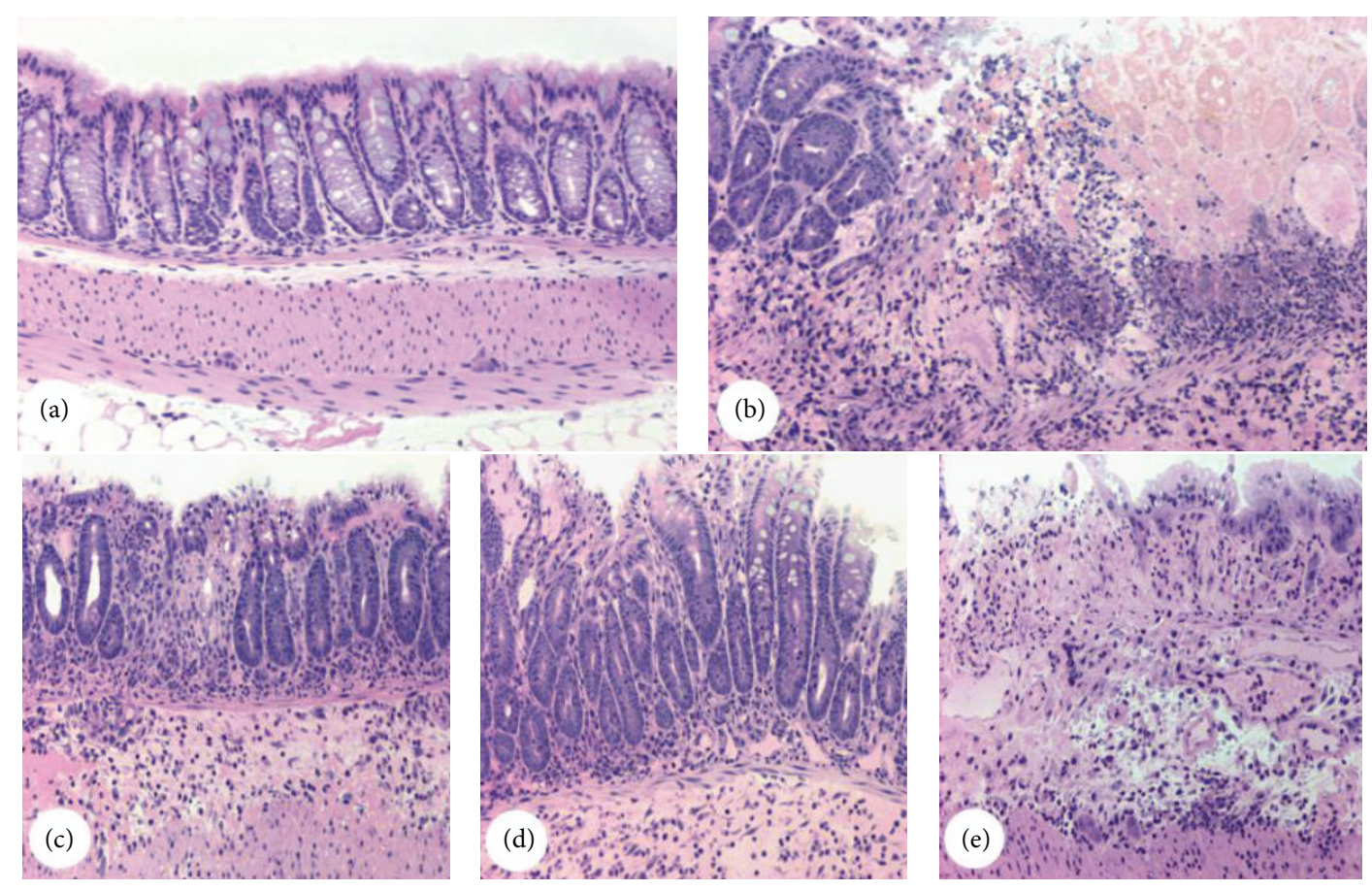

FIGURE 2: Representative light microscopy of colons from both colitic and noncolitic groups. Micrographs of the groups saline (a), TNBS (b), and RJ 100, RJ 150, and RJ 200 receiving both TNBS and royal jelly (c), (d), and (e), respectively. Hematoxylin and Floxin staining. Micrographs were taken using 10x objective lens. Each image is representative of 3 animals.

TABLE 2: Effect of royal jelly on colonic GSH level and GSH-Px and GR activities in TNBS-induced colitis in mice.

\begin{tabular}{lcc}
\hline Group & $\begin{array}{c}\text { Colon GSH levels } \\
(\mu \mathrm{mol} / \mathrm{mg} \text { of } \\
\text { protein) }\end{array}$ & $\begin{array}{c}\text { Colon GSH-Px activity } \\
(\mathrm{nmol} / \mathrm{min} / \mathrm{mg} \\
\text { protein })\end{array}$ \\
\hline Noncolitic (saline) & $25.1 \pm 5.91^{\mathrm{a}}$ & $5.0 \pm 0.28$ \\
Colitic (TNBS) & $8.6 \pm 1.10$ & $4.5 \pm 0.43$ \\
RJ $100 \mathrm{mg} / \mathrm{kg}$ & $22.8 \pm 3.11^{\mathrm{a}}$ & $11.8 \pm 3.18^{\mathrm{a}}$ \\
RJ $150 \mathrm{mg} / \mathrm{kg}$ & $12.6 \pm 3.06$ & $11.0 \pm 0.8$ \\
RJ $200 \mathrm{mg} / \mathrm{kg}$ & $5.62 \pm 2.56$ & $9.0 \pm 0.7$ \\
\hline
\end{tabular}

Results are presented as mean \pm SEM. ANOVA followed by Dunnett's $t$-test. ${ }^{a} P<0.05$ is significantly different from TNBS group.

3.5. Western Blotting Analyses. NF- $\kappa \mathrm{B}$ and COX-2 from colonic mucosa were measured by western blotting (Figures 3 and 4). The levels of expression of NF- $\kappa \mathrm{B}$ p 65 were detected in low quantity in nuclei of normal mucosa whereas a high expression of nuclear factor appeared in colon mucosa from control TNBS colitic group. Nonetheless, upon pretreatment with RJ $100 \mathrm{mg} / \mathrm{kg}$, the expression of NF- $\kappa \mathrm{B}$ p 65 was kept at lower levels than TNBS group (Figure 3). As shown in Figure 4, exposure of colon to TNBS caused strong expression of COX-2; on the other hand, RJ at $100 \mathrm{mg} / \mathrm{kg}$ induced downregulation of COX-2 when compared with TNBS group $(P<$ $0.001)$.

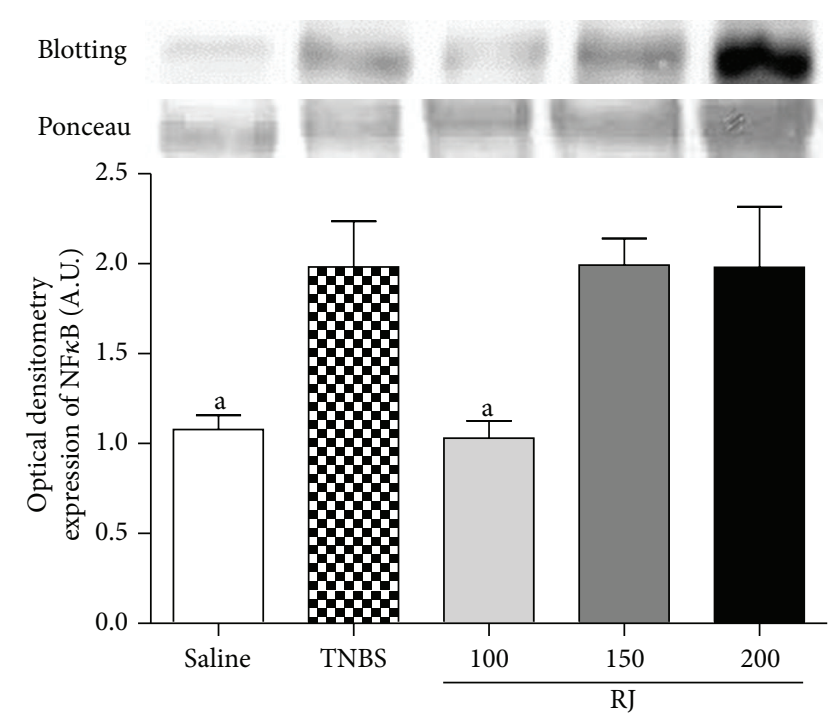

FIGURE 3: Representative Western blot analysis of analysis of NF$\kappa \mathrm{B}$. Densitometric data were studied following normalization to the control (Ponceau). The results are representative of three experiments performed on different samples and data are expressed as mean \pm SEM. ANOVA followed by Dunnett's $t$-test. ${ }^{a} P<0.05$ is significantly different from TNBS group.

\section{Discussion}

Ulcerative colitis (UC) and Crohn's disease (CD) are the two major forms of inflammatory bowel disease (IBD); both diseases share common features, despite differing in the etiology. 


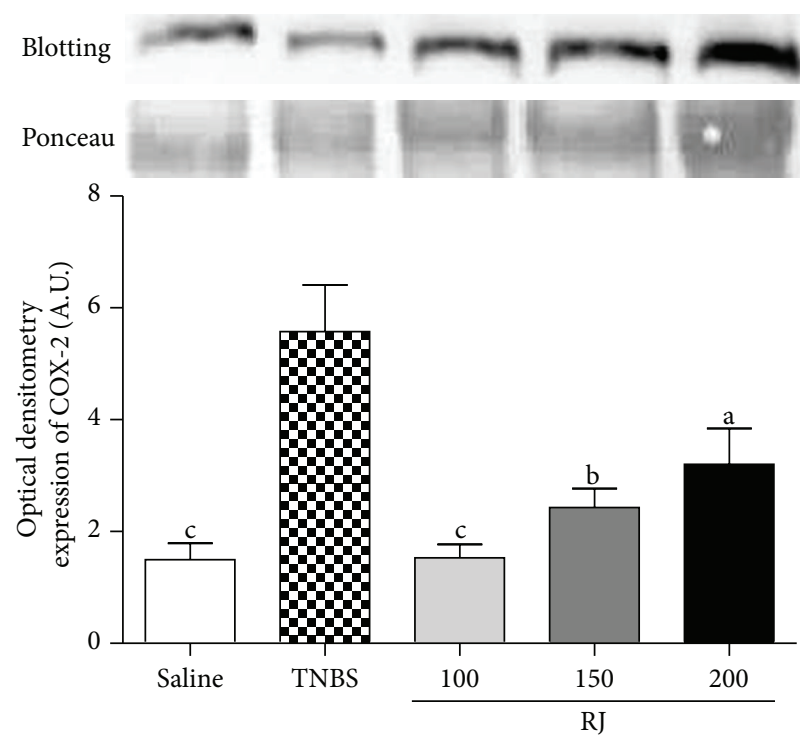

FIGURE 4: Representative Western blot analysis of COX-2 proteins. Densitometric data were studied following normalization to the control (Ponceau). The results are representative of three experiments performed on different samples and data are expressed as mean \pm SEM. ANOVA followed by Dunnett's $t$-test. ${ }^{\mathrm{a}} P<0.05,{ }^{\mathrm{b}} P<$ 0.01 , and ${ }^{\mathrm{c}} P<0.001$ are significantly different from TNBS.

These two forms of IBD are characterized by an exacerbated immune response towards enteric commensal microbial population [25]. The symptoms are also similar: abdominal pain, severe diarrhea, bloody feces, and consequent anaemia and weight loss. Some patients may lose up to $20 \%$ of the total weight in very short periods in the acute phase of the disease, which can be observed in animal models of experimental colitis. Animal models of intestinal inflammation are indispensable for our understanding of the pathogenesis of $\mathrm{CD}$ and UC. These models are used to evaluate new antiinflammatory strategies. One of the most widely used models is colitis induced by the hapten TNBS. It is thought that this model resembles Crohn's disease because of the resulting mucosal inflammation mediated by a Th1 response [26].

We have demonstrated that all colitic groups lost weight after TNBS induction and that the RJ $100 \mathrm{mg} / \mathrm{kg}$ group restarted weight gain more quickly than those of the TNBScolitic group. One must consider that this parameter alone does not indicate, by itself, any efficacy of the pretreatment; however, it gives us an idea of the general state of the animal. The weight loss can be partially explained by the reduction in chow consumption (data not shown) and water intake due to the damage in the colon, which, in turn, causes pain and intense diarrhea. The macroscopic evaluation is a very important tool when assessing experimental TNBS-induced colitis since it considers the size of the ulceration; hence, we can evaluate how damaged the tissue remains [19]. In the TNBScolitic group, the lesion area was large and showed extensive tissue thickening. RJ $100 \mathrm{mg} / \mathrm{kg}$ was effective in protecting the mucosa and keeping the lesion smaller than that of the TNBS group and also presented better macroscopic scores (Table 1). The macroscopic score presented by the dose of $200 \mathrm{mg} / \mathrm{kg}$ was not different from the TNBS one. Moreover, it is already known that the royal jelly may exert toxic effects if consumed in high doses or quantities [7-9]; some studies have already demonstrated that animals receiving high amounts of royal jelly presented high death rate due to its toxic effects, which was corroborated by our results. The mechanisms involving its toxicity are still not entirely elucidated, although one of the reasons may be likely to happen due to the presence of polyphenolic compounds in the RJ, including flavonoids [27]. Flavonoids present different biological activities such as antioxidant activity. There is evidence that this compound presents a dual effect, antioxidant or prooxidant, intimately depending on its concentration [28]. It is likely that the dose of $200 \mathrm{mg} / \mathrm{kg}$ is exerting a prooxidant effect.

Many aspects are involved in the inflammatory process, such as the oxygen reactive species (ROS), which have already been demonstrated to modulate the immune response. The respiration process is mandatory for the life of aerobic organisms, but it can be harmful due to the formation of ROS. Despite being considered foes, they play very important roles in living organisms. These molecules may exert an antibacterial function through protein, DNA, and lipid oxidation: on the other hand, when they are over produced, they become a threat to cells, due to their great oxidizing capacity [28]. There are extensive data showing that ROS are important players in the pathogenesis of IBD. Increased production of ROS harms the integrity of the epithelial cells, through an initial inflammatory response. In order to protect tissues against ROS-triggered injuries, all cells have antioxidant enzymes, including glutathione peroxidase (GSH-Px) and radical scavengers such as sulfhydryl compounds GSH [11].

GSH has already been shown to have its level diminished in experimental colitis [12]. This is part of the first line of defense against oxidative stress and the pretreatment with RJ $100 \mathrm{mg} / \mathrm{kg}$ was capable of increasing the levels of GSH (Table 2). These data suggest that RJ has the capacity of protecting intestinal mucosa from injuries, probably by protecting the depletion of this antioxidant barrier. These results are in accordance with previous studies showing that the RJ exerts a free radical scavenging activity [10], therefore ameliorating the ongoing inflammation.

Recent reports show that the cytosolic GSH-Px activity in rat colon tissues is altered in response to oxidative stress [29]. GSH-Px is an antioxidant enzyme that helps scavenging and inactivating $\mathrm{H}_{2} \mathrm{O}_{2}$, thereby protecting tissues from deleterious damage caused by the peroxide [30].

The activity of GSH-Px appeared reduced in TNBS-colitic groups (Table 2); this apparently paradox can be explained by the GSH and $\mathrm{H}_{2} \mathrm{O}_{2}$ dependence on the activity of the GSHPx. For the TNBS group, the limiting factor is the level of GSH (very low); on the other hand, for the non-colitic saline group, the limiting factor is the $\mathrm{H}_{2} \mathrm{O}_{2}$, that is not augmented, since there is no oxidative stress going on. In both cases, The RJ $100 \mathrm{mg} / \mathrm{kg}$ was capable of increasing the level of GSH as well as the activity of GSH-Px, demonstrating its antioxidant property (Table 2).

Evidences indicate that NF- $\kappa \mathrm{B}$, a ubiquitously expressed, proinflammatory eukaryotic transcription factor is important in the regulation of a broad spectrum of genes in many 


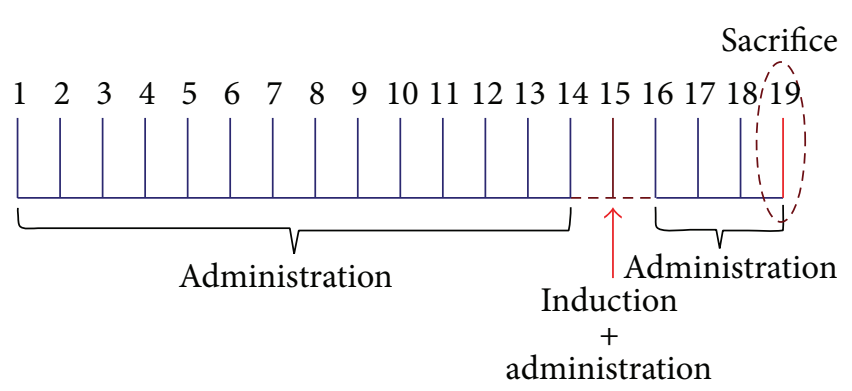

FIgURe 5: Pretreatment with Royal Jelly (100, 150, and $200 \mathrm{mg} / \mathrm{kg}$ ) for 14 consecutive days followed by the administration of TNBS (induction of colitis) on day 15 . The following 3 days (16, 17, and 18), animals received RJ $(100,150$, and $200 \mathrm{mg} / \mathrm{kg})$ and were sacrificed on day 19.

physiological and pathological events [31]. NF- $\kappa$ B p 65 protein is increased in the colonic biopsies of patients with active IBD and a direct correlation with severity was observed with their levels [31]. It has also been reported that the expression of NF$\kappa \mathrm{B}$ is augmented in experimental IBD [29]. Due to the importance of NF- $\kappa \mathrm{B}$, not rarely, researchers make huge efforts in understanding its biology for potential pharmacological uses. In our experimental model, the NF- $\kappa \mathrm{B}$ expression was shown to be augmented in the TNBS group, corroborating with reported data [30]. We have also demonstrated that an increase in the colonic level of NF- $\kappa \mathrm{B}$ was inhibited by the pretreatment with RJ $100 \mathrm{mg} / \mathrm{kg}$ when compared with TNBS group (Figure 4). This NF- $\kappa \mathrm{B}$ decreased level is an important parameter in the protection of the gut against chronic TNBSinduced intestinal inflammation model [32].

Cyclooxygenase-2 (COX-2) is one of various inflammatory mediators regulated by NF- $\kappa \mathrm{B}$. The induced form of COX enzyme is involved in numerous physiological responses, mainly inflammation, where they catalyze the synthesis of prostaglandins (PGs) from arachidonic acid [33]. Prostaglandin $\mathrm{E}_{2}\left(\mathrm{PGE}_{2}\right)$ is one of the most important biologically active prostanoids found throughout the gastrointestinal tract. Despite the fact that $\mathrm{PGE}_{2}$ regulates many physiological functions of the digestive tract, including mucosal protection, gastrointestinal secretion, and motility, it is also implicated in the pathophysiology of IBD [34]. COX-2 is an inducible inflammatory enzyme induced by growth factors, proinflammatory cytokines, tumor promoters, and bacterial toxins and is increased in TNBS-induced colitis [32]. There is sufficient data to support that the inhibition of this enzyme is beneficial during TNBS-induced colitis [35]. Our results showed that the TNBS group showed an increased expression of COX-2 compared with the noncolitic group and that the dose of RJ $100 \mathrm{mg} / \mathrm{kg}$ prevented the overexpression of COX-2, when compared with TNBS group. The expression of COX-2 is regulated by the NF- $\kappa \mathrm{B}$ and thus, its inhibition may lead to a decrease in the expression of COX-2. Karaca et al. [17] have reported that RJ was capable of reducing the colonic mast cell infiltration, which may stimulate the production of COX-2 as well [36]. These data together (COX-2 inhibition, NF- $\kappa$ B inhibition, and that presented by Karaca et al. [17]) accredits $\mathrm{RJ}$ as a potential candidate for the protection against IBD.

\section{Conclusion}

TNBS-induced colitis is a widely accepted model for IBD studies, mainly UC and $\mathrm{CD}$. According to the results shown and the data published, $\mathrm{RJ}$ remains as a prominent nutrient. We demonstrated that oral pretreatment with RJ may be effective in protecting the mucosa of mice in TNBS-induced colitis, partly explained by its antioxidant property, which consequently prevents proinflammatory mediators from acutely increasing. It is important, nevertheless, to state that more comprehensive studies need to be carried out in order to evaluate more parameters involved in different models of experimental colitis and that the doses of royal jelly intake must be cautious mainly due to the adverse effects caused by high doses.

\section{Conflict of Interests}

The authors declare that there is no conflict of interests regarding the publication of this paper.

\section{Acknowledgments}

The authors are thankful to Fundação de Amparo à Pesquisa do Estado de São Paulo (FAPESP) and Conselho Nacional de Pesquisa e Desenvolvimento (CNPq).

\section{References}

[1] M. F. Ramadan and A. Al-Ghamdi, "Bioactive compounds and health-promoting properties of royal jelly: a review," Journal of Functional Foods, vol. 4, no. 1, pp. 39-52, 2012.

[2] P. Moutsatsou, Z. Papoutsi, E. Kassi et al., "Fatty acids derived from royal jelly are modulators of estrogen receptor functions," PLoS ONE, vol. 5, no. 12, Article ID e15594, 2010.

[3] T. Sugiyama, K. Takahashi, and H. Mori, "Royal jelly acid, 10Hydroxy-trans-2-decenoic acid, as a modulator of the innate immune responses," Endocrine, Metabolic \& Immune Disorders-Drug Targets, vol. 12, no. 4, pp. 368-376, 2012.

[4] K. Kohno, I. Okamoto, O. Sano et al., "Royal jelly inhibits the production of proinflammatory cytokines by activated macrophages," Bioscience, Biotechnology and Biochemistry, vol. 68, no. 1, pp. 138-145, 2004.

[5] S. Watanabe, K. Suemaru, K. Takechi, H. Kaji, K. Imai, and H. Araki, "Oral mucosal adhesive films containing royal jelly accelerate recovery from 5-fluorouracil-induced oral mucositis," Journal of Pharmacological Sciences, vol. 121, no. 2, pp. 110-118, 2013.

[6] K. Niu, H. Guo, Y. Guo et al., "Royal jelly prevents the progression of sarcopenia in aged mice in vivo and in vitro," The Journals of Gerontology Series A: Biological Sciences and Medical Sciences, vol. 68, no. 12, pp. 1482-1492, 2013.

[7] F. C. Thien, R. Leung, B. A. Baldo, J. A. Weiner, R. Plomley, and D. Czarny, "Asthma and anaphylaxis induced by royal jelly," Clinical and Experimental Allergy, vol. 26, no. 2, pp. 216-222, 1996.

[8] M. Takahashi, I. Matsuo, and M. Ohkido, "Contact dermatitis due to honeybee royal jelly," Contact Dermatitis, vol. 9, no. 6, pp. 452-455, 1983. 
[9] Y. Yonei, K. Shibagaki, N. Tsukada et al., "Case report: haemorrhagic colitis associated with royal jelly intake," Journal of Gastroenterology and Hepatology, vol. 12, no. 7, pp. 495-499, 1997.

[10] J.-R. Liu, Y.-C. Yang, L.-S. Shi, and C.-C. Peng, "Antioxidant properties of royal jelly associated with larval age and time of harvest," Journal of Agricultural and Food Chemistry, vol. 56, no. 23, pp. 11447-11452, 2008.

[11] S. J. Dixon and B. R. Stockwell, "The role of iron and reactive oxygen species in cell death," Nature Chemical Biology, vol. 10, no. 1, pp. 9-17, 2014.

[12] V. Chiurchiù and M. MacCarrone, "Chronic inflammatory disorders and their redox control: from molecular mechanisms to therapeutic opportunities," Antioxidants and Redox Signaling, vol. 15, no. 9, pp. 2605-2641, 2011.

[13] F. M. de Faria, A. Luiz-Ferreira, E. A. R. Socca et al., "Effects of Rhizophora mangle on experimental colitis induced by TNBS in rats," Evidence-Based Complementary and Alternative Medicine, vol. 2012, Article ID 753971, 11 pages, 2012.

[14] D. Owczarek, D. Cibor, M. Szczepanek, and T. Mach, "Biological therapy of inflammatory bowel disease," Polskie Archiwum Medycyny Wewnetrznej, vol. 119, no. 1-2, pp. 84-88, 2009.

[15] J. Y. Cho, S.-G. Chi, and H. S. Chun, "Oral administration of docosahexaenoic acid attenuates colitis induced by dextran sulfate sodium in mice," Molecular Nutrition \& Food Research, vol. 55, no. 2, pp. 239-246, 2011.

[16] L. Márquez, B. G. Pérez-Nievas, I. Gárate et al., "Anti-inflammatory effects of Mangifera indica L. extract in a model of colitis," World Journal of Gastroenterology, vol. 16, no. 39, pp. 4922-4931, 2010.

[17] T. Karaca, F. Bayiroglu, M. Yoruk et al., "Effect of royal jelly on experimental colitis induced by acetic acid and alteration of mast cell distribution in the colon of rats," European Journal of Histochemistry, vol. 54, no. 4, article e35, 2010.

[18] G. P. Morris, P. L. Beck, M. S. Herridge, W. T. Depew, M. R. Szewczuk, and J. L. Wallace, "Hapten-induced model of chronic inflammation and ulceration in the rat colon," Gastroenterology, vol. 96 , no. 3, pp. 795-803, 1989.

[19] J. L. Wallace, W. K. MacNaughton, G. P. Morris, and P. L. Beck, "Inhibition of leukotriene synthesis markedly accelerates healing in a rat model of inflammatory bowel disease," Gastroenterology, vol. 96, no. 1, pp. 29-36, 1989.

[20] M. E. Anderson, "Determination of glutathione and glutathione disulfide in biological samples," Methods in Enzymology, vol. 113, pp. 548-555, 1985.

[21] T. Yoshikawa, Y. Naito, A. Kishi et al., "Role of active oxygen, lipid peroxidation, and antioxidants in the pathogenesis of gastric mucosal injury induced by indomethacin in rats," Gut, vol. 34, no. 6, pp. 732-737, 1993.

[22] M. Helenius, M. Hänninen, S. K. Lehtinen, and A. Salminen, "Changes associated with aging and replicative senescence in the regulation of transcription factor nuclear factor- $\kappa \mathrm{B}$," Biochemical Journal, vol. 318, part 2, pp. 603-608, 1996.

[23] M. M. Bradford, "A rapid and sensitive method for the quantitation of microgram quantities of protein utilizing the principle of protein dye binding," Analytical Biochemistry, vol. 72, no. 1-2, pp. 248-254, 1976.

[24] U. K. Laemmli, "Cleavage of structural proteins during the assembly of the head of bacteriophage T4," Nature, vol. 227, no. 5259, pp. 680-685, 1970.
[25] Y. Liu, Z. Zhang, L. Wang et al., "TLR4 monoclonal antibody blockade suppresses dextran-sulfate-sodium-induced colitis in mice," Journal of Gastroenterology and Hepatology, vol. 25, no. 1, pp. 209-214, 2010.

[26] A. A. te Velde, M. I. Verstege, and D. W. Hommes, "Critical appraisal of the current practice in murine TNBS-induced colitis," Inflammatory Bowel Diseases, vol. 12, no. 10, pp. 995999, 2006.

[27] A. M. Gómez-Caravaca, M. Gómez-Romero, D. Arráez-Román, A. Segura-Carretero, and A. Fernández-Gutiérrez, "Advances in the analysis of phenolic compounds in products derived from bees," Journal of Pharmaceutical and Biomedical Analysis, vol. 41, no. 4, pp. 1220-1234, 2006.

[28] J. Bouayed and T. Bohn, "Exogenous antioxidants-doubleedged swords in cellular redox state: health beneficial effects at physiologic doses versus deleterious effects at high doses," Oxidative Medicine and Cellular Longevity, vol. 3, no. 4, pp. 228237, 2010.

[29] N. Kannan and C. Guruvayoorappan, "Protective effect of Bauhinia tomentosa on acetic acid induced ulcerative colitis by regulating antioxidant and inflammatory mediators," International Immunopharmacology, vol. 16, no. 1, pp. 57-66, 2013.

[30] E. A. Rabelo Socca, A. Luiz-Ferreira, F. M. De Faria et al., "Inhibition of tumor necrosis factor-alpha and cyclooxigenase- 2 by Isatin: a molecular mechanism of protection against TNBSinduced colitis in rats," Chemico-Biological Interactions, vol. 209, no. 1, pp. 48-55, 2014.

[31] A. Siomek, "NF- $\kappa$ B signaling pathway and free radical impact," Acta Biochimica Polonica, vol. 59, no. 3, pp. 323-331, 2012.

[32] G. Rogler, K. Brand, D. Vogl et al., "Nuclear factor $\kappa$ B is activated in macrophages and epithelial cells of inflamed intestinal mucosa," Gastroenterology, vol. 115, no. 2, pp. 357-369, 1998.

[33] M. E. Spehlmann and L. Eckmann, "Nuclear factor-kappa B in intestinal protection and destruction," Current Opinion in Gastroenterology, vol. 25, no. 2, pp. 92-99, 2009.

[34] I. Dey, M. Lejeune, and K. Chadee, "Prostaglandin E 2 receptor distribution and function in the gastrointestinal tract," The British Journal of Pharmacology, vol. 149, no. 6, pp. 611-623, 2006.

[35] D. G. Binion, M. F. Otterson, and P. Rafiee, "Curcumin inhibits VEGF-mediated angiogenesis in human intestinal microvascular endothelial cells through COX-2 and MAPK inhibition," Gut, vol. 57, no. 11, pp. 1509-1517, 2008.

[36] H. Behzad, A. Sharma, R. Mousavizadeh, A. Lu, and A. Scott, "Mast cells exert pro-inflammatory effects of relevance to the pathophyisology of tendinopathy," Arthritis Research and Therapy, vol. 15, no. 6, article R184, 2013. 


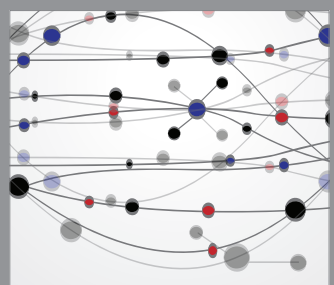

The Scientific World Journal
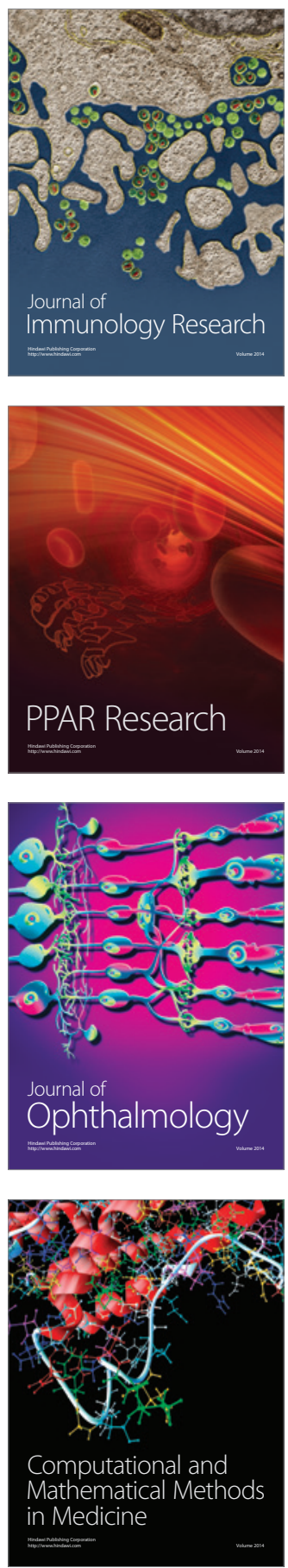

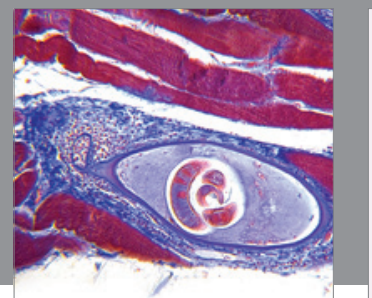

Gastroenterology

Research and Practice
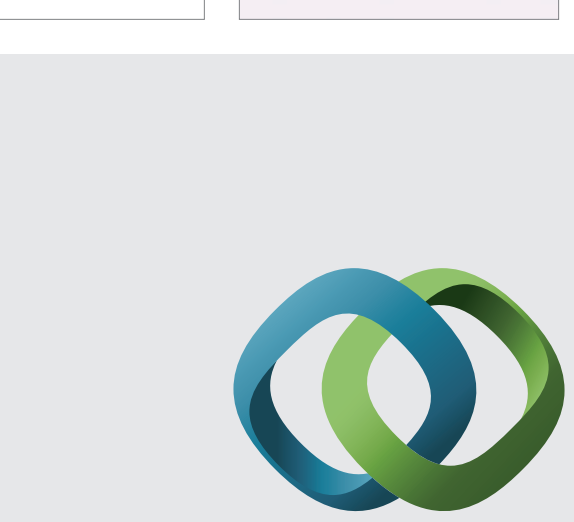

\section{Hindawi}

Submit your manuscripts at

http://www.hindawi.com
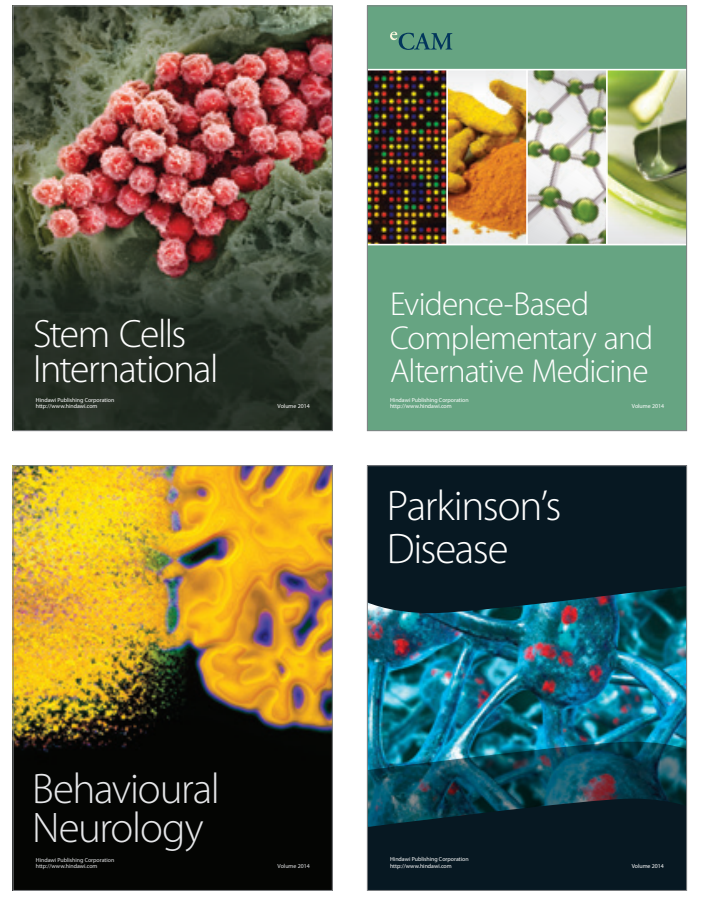
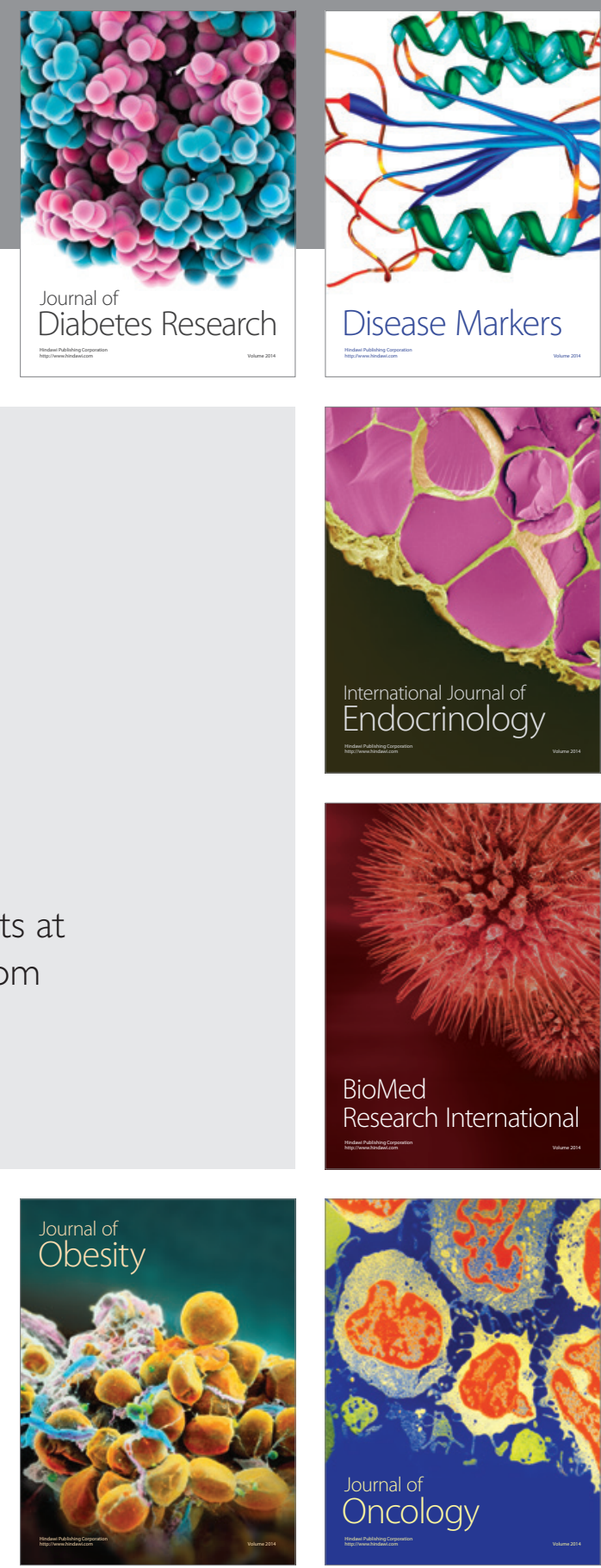

Disease Markers
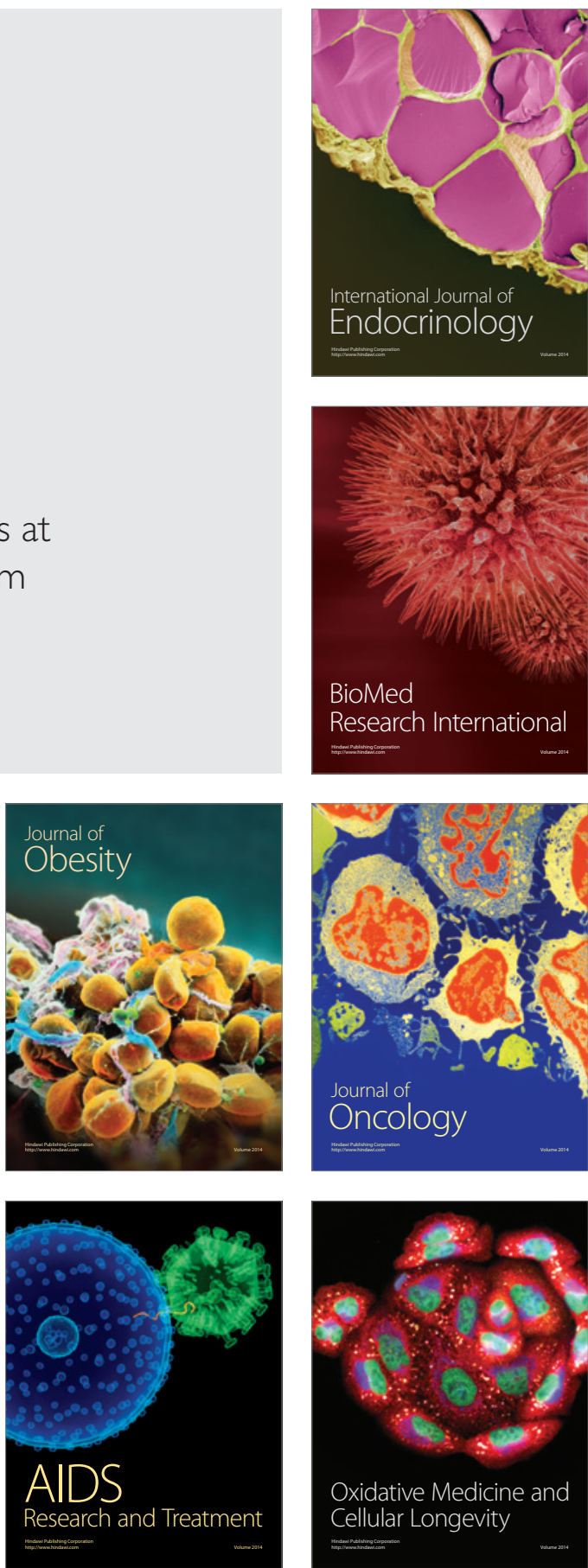